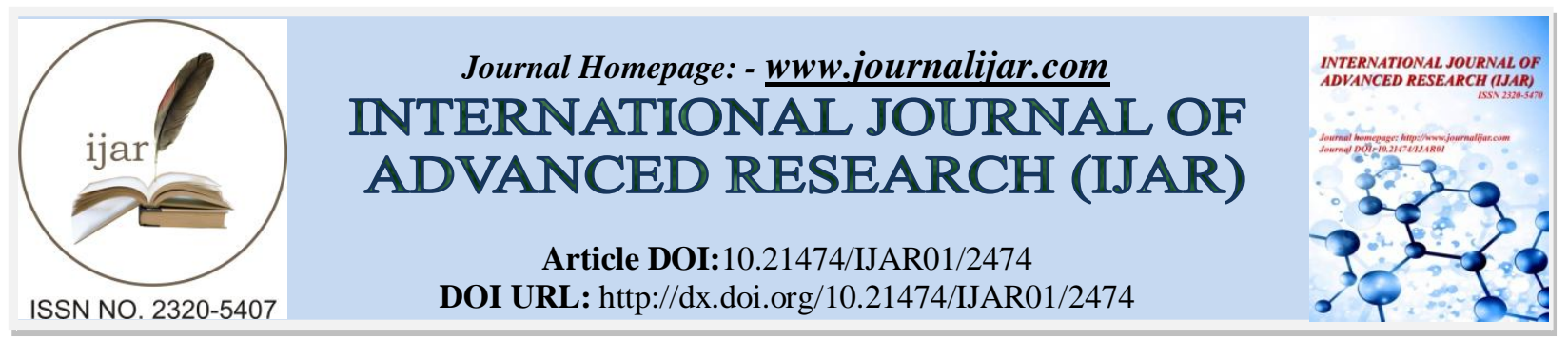

RESEARCH ARTICLE

\title{
A FEMINIST STUDY OF GIRISH KARNAD'SNAGA- MANDALA
}

\section{Kempanna Rachappa Donawad}

Research Scholar,Department of EnglishSri SatyaSai University of Technology and Medical Sciences,Sehore, Indore-Bhopal Road, Madhya Pradesh.

\section{Manuscript Info}

\section{Manuscript History}

Received: 23 October 2016

Final Accepted: 21 November 2016

Published: December 2016

Key words:-

Technique,Feminist,Myth,Folk,Theatre

\section{Abstract}

Naga-Mandala is a play on the emancipation and empowerment of the women who have to play a vital role for the regeneration of a degenerate social order. Rani, the heroine of the play, who is humiliated and derided as a 'harlot' before the village elders, undertakes the 'snake ordeal'. She comes outoure. She is elevated to divinity and is hailed by all as a goddess. Her husband Appanna realizes his mistakes, accepts her with all humility and feelings of sincere remorse and repentance.

Copy Right, IJAR, 2016,. All rights reserved.

\section{Introduction:-}

GirishKarnad's plays highlights contemporary Indian cultural and social life through the use of folk tales, tradition, myths and historical legends. GirishKarnad's plays and the plays of his contemporary playwrights have to be studied in a socio-historical perspective of his time. It was a period of transition and tension between the cultural past of the country and the colonial past, between two different pulls and attraction-one of our own tradition and another of the western mode of thought. Actually this conflict gave rise to his plays. In order to articulate himself he takes recourse to myth and history. He always found it difficult to find a suitable plot for writing a play. After Yayati he looked up several books to find out, a plot for his next play. While reading the history of Kannada literature by KirtinathKurtkote he learnt, "Indian history has not been handled by any Indian writer the way it has been done by Shakespeare or Brecht," (Dhawan 15).

GirishKarnad'sNaga-Mandala, based on two Kannada folktales which he heard from A.K. Ramanujan, is full of mythical wonder and is enshrouded in a realm of magic and supernaturalism. Naga-Mandala begins with a prologue in which man is Sutradhar who addresses the need of story-telling to the audience in a mode of fantasy. This story is presented in the play by a woman narrator, a "flame" which has come to tell a story. The play begins in the temple on the outskirts of a village, where a passer-by stops at night for a shelter. He then finds many tiny "flames" have come from different households in the village. Each flame is a female, a story-teller, sharing with the others her observations and new experiences. The stranger, a writer himself, enters into their conversation, and listens to a 'new' tale that has just escaped from an old woman's head. Naga-Mandala is the story of a cobra turning into a man at will. There is a coupleAppanna (any man) and Rani. Appanna is totally indifferent to Rani who is locked inside the house all alone. He comes to the house only for his lunch, spends the whole night and day away with his concubine.

There are themes of patriarchal tyranny, female and male sexuality, adultery and chastity and it enables the playwright to present a complex human experience. This transmutation is responsible for the transformation of the characters of Rani and Appanna.As the play opens, Appanna is portrayed as a very dominating and cruel husband 
who exercises absolute superiority over his bride. He locks her in the house. When he notices Kurudavva, the blind women and her son, Kappanna near his house, he gets a watch dog to scare them off. Kappanna says, "Appanna should have been born a blind beast or a reptile. By some mistake, he got human birth" (8). Initially, Rani feels a passive victim of her husband's oppression. Rani is a extremely innocent and naïve woman. She does not even comprehend the meaning of sex. When kurudavva questions her, "Has your husband touched you? How can I put it? Did anyone explain to you before your wedding? You mother? Or and aunt?" (11), she looks blank. Kurudavva, the best friend of Appanna's mother takes pity on her and gives her piece of a root to feed him secretly. But it does not yield the desired result. A Cobra who lives near by under a tree is charmed by the root mixed curry that is poured on it by Rani. It changes into Appanna and sleeps with her at night. She is baffled to see the difference of attitude between Appanna at night and Appanna in the day. But she does not understand anything. She learns to bear with the diabolic character of her husband. She gets pregnant. Appanna is shocked for he knows that he cannot be the father of the baby. He abuses her and accuses her of being a whore.She is put to trial by the village panchayat. She is then asked to prove her fidelity by putting her hand in the snake burrow and taking a vow that she has not committed adultery. It is a popular belief that if any person lies holding the snake in their hand, they will be instantly killed by the snakeGod.

She does place her hand in the snake burrow and vows that she has never touched any male other than her husband and the Naga in the burrow. Rani is asked by the man at night, whom she takes to be her husband, to "speak the truth... what you think is not of a consequence. It must be the truth." (54).The truth for Rani is that she has been faithful to her husband. She is declared chaste by the village Panchayat.The nervous, frightened, young girl finds within herself a new courage and confidence and gain social respectability. She emerges triumphant from the public trial, as the snake does not bite her. The cold, aggressive and indifferent husband is subdued, mildly tamed and accept the judgement even if he is not fully convinced.

Naga-Mandala can be approached as a feminist play with a difference.It raises feminist issues like child marriage, exploitation of wife at the hands of husband, double standard of the society as well as of the law operating in it. Again it exposes effectively the hollowness and injustice of patriarchal family system. In Naga-Mandala the context is female oriented.But at the same time it is different from the common feminist writings in the sense that it does not advocate any 'ism' as the feminist does. It does not offer any alternative system. It does not reject the husband or men in the life of women. It seeks only reform in man's attitude. The most important difference is that in NagaMandala individuals are subservient to society and family. So the final judgment goes in favour of the continuation of the existing family system.

Appanna and Rani are married at a very early age. When Rani became young Appanna took her to his home. He has an illicit relationship with a concubine. He continues with it and ignores his wife. He neither talks to her nor spends his night with her. She is thus forced to live all alone in his house day dreaming or weeping. He only comes to have his bath and lunch and then goes out after locking the door from outside. So Rani is victimized for no fault. She is innocent of her biological needs but certainly she wants love and care and time of her husband. She says to kurudavva.

Rani : I am so frightened at night, I can't sleep a wink. But here alone-Kurudavva can you help me please? Will you please send word to my parents that I am, like this, here? Will you ask them to free and take me home? I would jump into a well-if I, only I could. (32)

Rani is so meek that she does not question his luxurious nights elsewhere or quarrels with him over his relation with a concubine. When she wants to plead she fumbles for words: "Listen- I feel- frightened-alone at night." (28).Appanna either does not talk to her or speaks in monosyllables, mostly imperative sentences like, "Do as you are told, you understand?" It is the cold indifference of Appanna that tortures Rani. He does not bear her or ill-treat her in literal terms but on two occasions he beats Rani. First when Rani goes out to pour the root mixed curry into the ant-hill. He asks Rani from the bathroom what is bothering the dog. She does not reply. When she comes in,Appannna slaps her hard. Rani collapses to the floor and he goes out leaving her locks the door from outside. She is not allowed to talk to anyone even to Kurudavva. This creates suspicion in his mind leading to communication gap between them. In fact, she is treated not worth keeping communication. Rani is put to trial to prove her chastity. But no one questions Appanna for his extra-marital relationship with a harlot. Why has he not given the right of a wife to Rani? The elders doing justice do not bother to ask this question. The play brings out this glaring 
discrepancy in our social as well as legal system. The gender bias is an important issue addressed in the play. The very system of trial for women is inhuman. The Elder III says :

The traditional test in our village court has been to take the oath while holding a red-hot iron in the hand. Occasionally, the accused has chosen to plunge the hand in boiling oil. But you insist on swearing by the king Cobra. (55)

The second time he beats her and abuses her when he discovers that she is pregnant. Since he has never slept with her he knows that she has committed adultery. This infuriates him and he pushes, kicks and abuses her:

Appanna : Aren't you ashamed to admit it, you harlot? I locked you in and you yet managed to find a lover!

Tell me who it is. Who did you go with your Sari off?

Rani : I swear to you. I haven't done anything wrong! (53)

And it is here that she first willingly commits disobedience to her husband. He drags her out and tries to throw a huge stone at her. But the snake hisses and he throws it to him. Rani at once gets in and bolts the door behind her. He demands her to open the door but she refuses. This is her first disobedience in an abnormal situation to escape his wrath. Otherwise she is carved out a docile woman. It can also be seen as her defiance and protest. But on the whole she is a conformist character and is not revolting. However, she does want change. Since she has not matured enough to revolt, she realizes the change through supernatural intervention. Naga with a magical power to assume any form or shape plays crucial role in bringing about the reconciliation. She successfully undergoes the snake ordeal. The Cobra slides up her shoulder and spreads its hood over her head. This immediately gives her a divine status.

Elder I :Appanna, your wife is not ordinary woman. She is a goddess incarnate. Don't grieve that you judged her wrongly and treated her badly. That's how goddesses reveal themselves to the world." (59)

One may wonder if this judgement is for Rani, a common woman or for a divine Rani. In this way Naga as a deity fulfills her desires which she does not express openly. She grows up mentally and is cured of her fragility. Karnad uses the folk tale in its feminized form to present the problems faced by both man and woman in marriage and the process of transformation of the immature and emotionally under-developed person into a mature and fully grown adult.Karnad'sNaga-Mandala is a feminist play. It questions patriarchal moral code which demands the faithfulness of a woman to her husband but not the faithfulness of a husband to his wife.Naga-Mandala, a simple but magical tale, celebrates sensuality from a women's point of view.

\section{References:-}

1. Dhawan,R.K: "GirishKarnad:The Man and the Writer", The Plays of GirishKarnad. New Delhi :Prestige Books, 2008.Print.

2. Karnad,Girish.ThreePlays:Naga-Mandala,Hayavadana,Tughlaq.NewDelhi:OxfordUniversity Press ,2002.Print. 